\title{
Environmental impact of tobacco growing in Tabora/Urambo, Tanzania
}

\author{
John Waluye
}

Tanzania is Africa's fourth largest producer of tobacco, growing flue-, fire-, and air-cured (burley) varieties, mainly in central western Tanzania and the Southern Highlands. In 1993 it grew 21000 tonnes of tobacco. ${ }^{1}$ Since independence in 1961, the crop has been mostly grown by small-holder farmers who use the hand-hoe, with little or no use of mechanised equipment.

This case study concentrates on tobacco production in the central western part of Tanzania - the Tabora region - where two districts, Tabora rural and Urambo districts, contribute about $68 \%$ of the tobacco produced in Tanzania. Introduced by the British colonial government after a failed groundnuts scheme, tobacco has become the major cash crop for people in the region, despite its labour intensity.

Although the two areas have been cultivating tobacco since independence, the motivating factor for increased production was World Bank sponsorship of the crop in the 1970s. Tobacco complexes were established and each was given the necessary input and expertise using World Bank finance. According to figures from the Tobacco Authority of Tanzania, tobacco production increased significantly and tobacco-growing families more than quadrupled from 6070 in 1970 to 25880 in 1978. The area under tobacco cultivation also expanded from 5540 ha to over 12000 ha in this period.

For many years farmers were able to get their flue-curing firewood supplies by cutting trees readily available in the natural forests of the Miombo woodlands. But as time went by, these trees were depleted and farmers are now forced to travel more than $10 \mathrm{~km}$ to get wood. Coupled with the fact that wood fuel is the main source of domestic energy for most Tanzanians, trees cut to cure tobacco have accelerated the rate of deforestation. The current rate of all-cause deforestation in Tanzania stands at between 300000 and 400 000 ha (42 $000000 \mathrm{~m}^{3}$ of solid wood) per annum. During the $1991 / 92$ season, a total of about $466500 \mathrm{~m}^{3}$ of wood fuel - about $1 \%$ of the national total - was used to cure tobacco in the Tabora rural and Urambo districts.

Since tobacco growing is rotational and is

Journalists'

Environmental

Association of Tanzania, PO Box 9033, Dar-esSalaam, Tanzania J Waluye

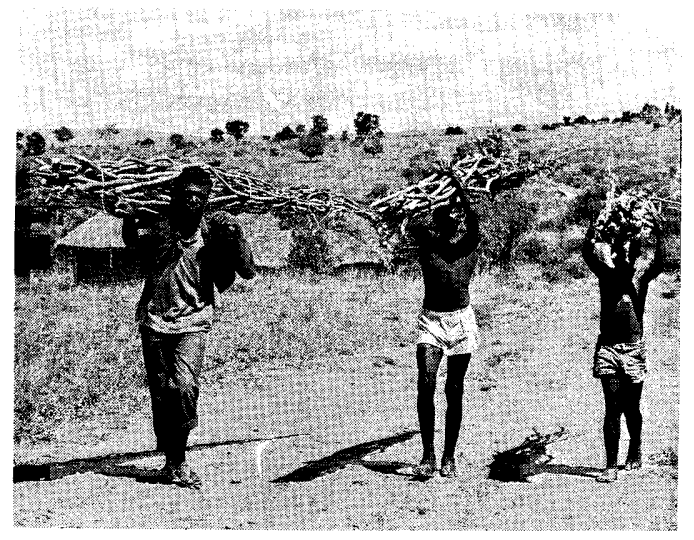

is planted with maize, the crop harvests are generally good. Rotational tobacco farming also helps avoid the risk of the crop being attacked by rootknot nematodes. However, the impact of tree-felling from this rotational farming has now turned the area into an environmental disaster which requires urgent and concerted efforts to reverse.

Growing and tree-cutting are increasing The Tanzania Tobacco Production and Marketing Board (TTPMB), which buys all tobacco produced in Tanzania, is pleased that the number of growers is increasing each year, thereby increasing production. Last season's prices, which averaged between 162 shillings/ $\mathrm{kg}$ (US $\$ 0.36$ ) for tips and 505 shillings/kg (US\$1.12) for leaf, motivated growers to increase production. Since the 1991/92 season, small-holder farmers have been receiving second payments averaging 260 shillings $/ \mathrm{kg}$ (US0.58) after the crop has been sold in international markets. Such an incentive to peasant farmers with meagre annual incomes stimulated increased hectarage in the next farming season.

\section{Case study}

Mr Freddy Lusekelo, a peasant farmer from Ntalikwa village in Tabora district, started growing tobacco in 1983 . He cultivated 1.6 ha of tobacco in 1985, producing $650 \mathrm{~kg}$, which earned him 300000 shillings (US\$667). By the 1992/3 season, Mr Lusekelo cultivated 8.5 ha, producing $13955 \mathrm{~kg}$ worth 6739980 shillings (\$US14 978). Next season, he expects to cultivate 24 ha of tobacco, trebling last season's cultivated land area.

$\mathrm{Mr}$ Lusekelo has become a model farmer for open new areas for the crop, while the previous areas are put under other crops such as maize. Because fertiliser is used for cultivation of tobacco, when land previously under tobacco 
dignitaries visiting tobacco farms in the district. Last season, he was granted a 2.5 million shilling loan from the National Bank of Commerce to facilitate his tobacco production. He says that he had already paid back the loan with the money he received after selling his $13955 \mathrm{~kg}$.

When $\mathrm{Mr}$ Lusekelo moved to Ntalikwa village in 1983, he got all his firewood requirements from the natural forest only metres from his compound. However, as his hectarage of tobacco increased, he has had to look further for firewood. Last season, he got firewood some $12 \mathrm{~km}$ away, and had to hire a tractor at a cost of 8000 shillings (US\$18) per trip to bring it to his tobacco barns.

This story is typical of farmers growing tobacco in the two districts. Although they know why firewood to cure their tobacco has become scarce, farmers seem not to be taking seriously the campaign of "cut a tree, plant a tree", launched by the government 10 years ago. Although considered a model farmer, $\mathrm{Mr}$ Lusekelo has only 155 trees planted on his plot. Although records of the TTPMB show that last year they distributed some 2500 tree seedlings to him, he cannot account for the other trees, which might have died due to the drought which hit the area in the past three years.

Urambo district manager for the TTPMB, Mr Ephraim Lema, notes that in the 1992/93 season, the Board distributed 179326 tree seedlings to villages and individuals. However 14076 were not planted for various reasons. Mr Lema thinks that because the seedlings are distributed free of charge to tobacco growers, the growers do not feel any sense of responsibility to care for them - hence the low rates of survival of the trees. For this reason, the Board has this year prepared only 100000 tree seedlings for distribution. Distribution and monitoring of the planting of trees is the responsibility of the Forestry Department of the Ministry of Natural Resources and Environment. Formerly, the Board gave the Forestry Department funds for raising tree nurseries for later distribution to tobacco growers, but forestry officials are alleged to. have squandered the money. The Department has not prepared tree nurseries for several years, or enforced the "cut a tree, plant a tree" campaign.

The type of tree seedlings offered to tobacco growers are mostly eucalyptus. These are unpopular because they draw a lot of water from the ground, resulting in the area becoming dry. When the TTPMB started distributing tree seedlings in the mid $1980 \mathrm{~s}$, most of the seedlings were planted in communal village plots. These trees did not survive. Most of them were either destroyed by cattle, or dried out as there was no one to care for them.

Under the national campaign of tree planting which commenced more than 10 years ago, every person in the country was supposed to plant 20 trees per year, but the Ministry of Tourism, Natural Resources and Environment estimates that only one tree is planted per person per year. With this rate, very few trees are planted annually compared to those cut down for tobacco curing, charcoal, timber, and other uses.

Available data show that only between 12 000 and 22000 ha of land is planted with trees annually throughout Tanzania, compared with between 300000 and 400000 ha of trees lost annually through all-cause deforestation. Because most of the natural trees that are being cut down have very long regeneration periods of 30-50 years (Brachystegia, Boehmii, Pterocarpus angolensis, Brachstegia speciformis, and Fulbernadia globiflora), this has resulted in large areas being denuded of trees. From the air, the rural Tabora and Urambo districts look bare, especially near tobacco-growing villages.

About 50 years ago, Tanzania's area of natural forests stood at about 44000000 ha but this has now been almost halved. If deforestation is left unchecked, on present trends the country will lose all its forests in the next 17 years. To give a rough idea of how many trees are cut down to supply tobacco barns, it takes between 25 and $35 \mathrm{~m}^{3}$ of solid wood to cure $1000 \mathrm{~kg}$ of tobacco leaves. For the 21079 $715 \mathrm{~kg}$ of tobacco produced this season, between 526975 and $737790 \mathrm{~m}^{3}$ of solid wood were used to cure the crop ${ }^{\star}$.

\section{What should be done?}

The Tobacco Board also tried to push for the enactment of by-laws whereby, for example, each villager would be forced to set aside $10 \%$ of his or her land to plant trees for housing and tobacco curing. However, the by-law idea has not been received well by local councils.

Another idea mooted is that each farmer should be allocated a plot of land sufficient to plant tobacco and food crops, and another to leave fallow, together with a woodlot, which should be inspected by officials from the TTPMB. Registration as a tobacco farmer should not be granted until the farmer plants a sizeable land with trees.

Tabora Regional Development Director $\mathrm{Mr}$ David Masanja believes there should be deductions from the proceeds of every kilogram of tobacco sold, which should be put into a fund to be used in tree-planting activities. Money from the fund would be used to start tree nurseries and to employ personnel who will undertake distribution, planting, and care of the tree seedlings planted in the villages. $\mathrm{Mr}$

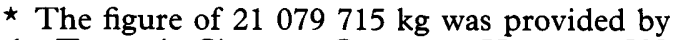
the Tanzania Cigarette Company. However, US Department of Agriculture (USDA) data show that for each year 1991-3, Tanzania grew 11000 tonnes of flue-cured and 3000 tonnes of firecured tobacco. A spokesperson for the USDA has commented "we have very little information with regard to the current tobacco situation in much of the less developed world. The figures that we do have in many instances are estimates based on past information....but for the most part we continue to carry these figures forward until we receive new data." (USDA Foreign Agriculture Service. Data supplied by PW Burr, 12 January 1993.) 
Massanja says that short of implementing such a plan, the Tabora region will turn into desert. Indeed, the effects of desertification are already visible. The region has for the past three years experienced drought; rains are now irregular; and whirlwinds which were uncommon in the region are now commonplace.

Tabora regional authorities are largely to blame for this state of affairs, as tobacco farmers have been little educated on treeplanting, hence their laissez-faire attitude. The Forestry Department in this region has not involved itself fully in preparation of nurseries and distribution of trees. If the Forest Department could ban lumbering in the region for at least three years, and could launch a strict tree-planting campaign in tobacco-growing areas, the ongoing deforestation process could be slowed down

Possibilities for replacing tobacco with other crops seem remote, as tobacco has proved to be a cash generator for the regional peasants. Further, because two-thirds of all tobacco produced is now exported, tobacco brings the country valued foreign exchange. If plans of the Tanzania Cigarette Company materialise this year to begin an extension services programme in Tabora and Urambo districts as it used to do in the 1960 s for tobacco growers, this might also save the already deforested areas. Through these services, growers would be provided with tree seedlings and expertise to ensure that the seedlings survive and grow to maturity. Under the programme, an afforestation campaign would be promoted and there would also be development of catchment areas and dams. This programme, to be funded by a joint venture between the TCC and Incotra of
Austria, aims at improving the quality and quantity of tobacco per hectare. This is contrasted with the situation at present whereby only quantity matters, resulting in more trees being felled to cure the crop.

Another alternative that might slow down the deforestation process in the area, is for authorities to ensure that tobacco growers switch from using standard barns to "low profile" or "malakis" barns, which have lower consumption rates of firewood. Because coal can be used to cure tobacco, the government could plan the construction of a tar road from Kiwira Coal Mine in Mbeya region, to Tabora. A distribution network could then be worked out so that coal is used to cure tobacco, and thus natural forests could be saved from depletion.

The government has the capacity to reverse the deforestation process in the Tabora/ Urambo area due to tobacco growing. Concerted efforts need to be taken by regional authorities to educate tobacco growers on sustainable agriculture vis- $a$-vis the environment. If these plans are not effected, Tabora region will, in the next few years, turn into a desert, with all the related problems. Of course, the government will receive greatly reduced foreign exchange from tobacco when its production consequently falls.

I would like to acknowledge the following sources of information: interviews with officials of the TTPMB; the Tanzania Cigarette Company; the Ministry of Natural Resources, Tourism and Environment; the Tumbi Agricultural Research Centre, Tabora; Tabora regional authorities; tobacco growers and individuals of Tabora and Urambo districts; $\mathrm{Mr}$ Rwechungura, Claphs.

1 US Department of Agriculture, Foreign Agriculture Service. World Tobacco Situation 1993. June, 1993.

$=$

$\therefore$

the

3

$=$

$x$

;

t

$=$

23

5

3

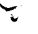

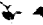
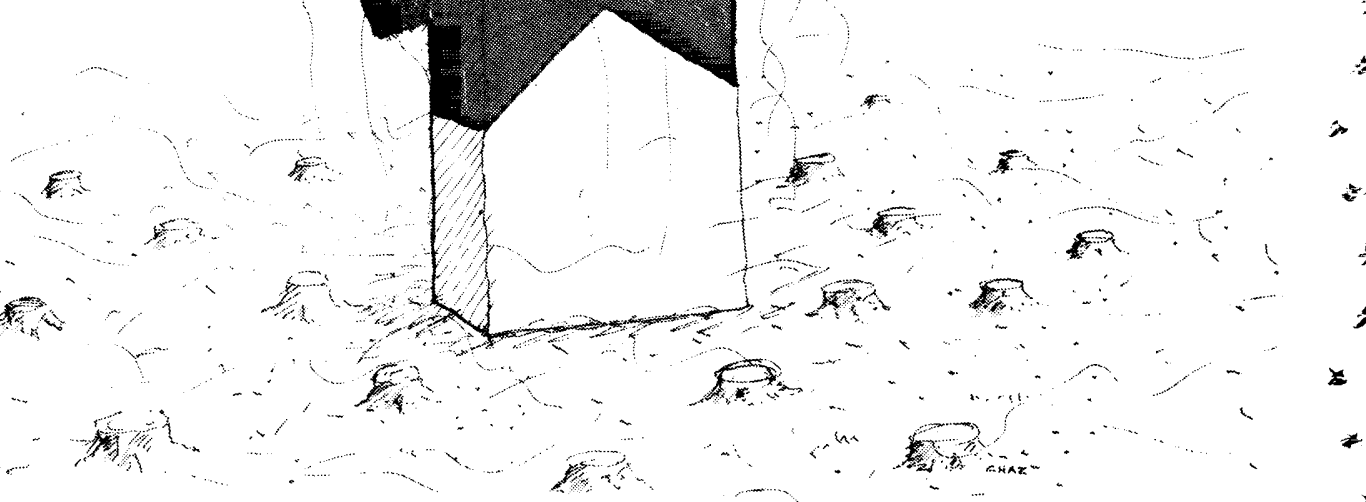